\title{
PENINGKATAN PEMAHAMAN DIRI MELALUI MODEL PERMAINAN JOHARI WINDOW SISWA KELAS X AK 3 SMK SORE KOTA MADIUN TAHUN PELAJARAN 2012/2013
}

\author{
Puput Tri Anjanisari *) \\ Dahlia Novarianing Asri **)
}

\begin{abstract}
Abstrak
Berdasarkan hasil observasi awal yang telah dilakukan peneliti di lapangan dan wawancara dengan konselor sekolah, diketahui bahwa kurang lebih 70\% siswa kelas X Ak 3 di SMK SORE Kota Madiun Tahun Pelajaran 2012/2013 memiliki pemahaman diri yang masih rendah. Cara yang digunakan untuk meningkatkan pemahaman diri siswa adalah dengan menggunakan model permainan Johari Window. Model Johari Window merupakan model permainan yang dapat digunakan untuk meningkatkan kesadaran diri (self-awareness) dan pemahaman diri (self understanding) pada individu.

Penelitian ini bertujuan untuk mengetahui peningkatan pemahaman diri melalui model permainan Johari Window siswa kelas X Ak 3 SMK SORE Kota Madiun tahun pelajaran 2012/2013.

Penelitian ini dirancang dengan menggunakan metode penelitian eksperimen dengan desain pre-test and post test group. Populasi dalam penelitian ini adalah siswa kelas X Ak 3 SMK SORE Kota Madiun. Pengambilan sampel dalam penelitian ini menggunakan teknik sampel jenuh yaitu siswa kelas X Ak 3 sebanyak 20 siswa. Pengumpulan data untuk mengetahui tingkat pemahaman diri siswa sebelum dan sesudah diberikan model permainan Johari Window dalam penelitian ini menggunakan metode angket. Dalam menganalisis data menggunakan teknik $t$-test.

Hasil analisis data menunjukkan bahwa ada perbedaan pemahaman diri siswa sebelum dan sesudah diberikan model permainan Johari Window yang berarti ada peningkatan pemahaman diri melalui model permainan Johari Window siswa kelas X Ak 3 SMK SORE Kota Madiun tahun pelajaran 2012/2013.
\end{abstract}

Kata Kunci : Pemahaman Diri, Model Permainan Johari Window.

* Puput Tri Anjanisari adalah Mahasiswa Program Studi Bimbingan dan Konseling Fakultas Ilmu Pendidikan IKIP PGRI Madiun.

* Dahlia Novarianing Asri adalah Dosen Program Studi Bimbingan dan Konseling Fakultas Ilmu Pendidikan IKIP PGRI Madiun. 


\section{PENDAHULUAN}

Masa remaja merupakan salah satu tahap perkembangan sepanjang rentang kehidupan manusia yang penuh dengan masalah, tantangan, dan harapan. Remaja dihadapkan pada tugas perkembangan sosial yang harus diselesaikan yaitu pembentukan identitas diri. Pembentukan identitas diri pada remaja merupakan hal yang sangat penting karena jika identitas diri ini tidak terbentuk, remaja akan mengalami krisis identitas. Remaja yang tidak berhasil mengatasi krisis identitas akan menderita kebingungan identitas, yang dapat mengakibatkan remaja menarik diri, mengisolasi diri dari kawan-kawan, dan menampilkan kepribadian yang tidak jelas dan terombang-ambing. Masa remaja merupakan usia dimana individu mulai merencanakan dan mencapai kematangan karier. Pemahaman diri merupakan aspek yang sangat penting untuk diketahui oleh individu usia remaja dalam membantu pembentukan identitas diri remaja dan mencapai kematangan karier.

Hal yang mendasar dari identitas diri adalah pemahaman diri. Seperti yang dikemukakan oleh Damon \& Hart (dalam Santrock, 2003:333), walaupun tidak membentuk identitas pribadi secara utuh, pemahaman diri memberikan dasar identitas diri yang rasional. Individu dikatakan telah memahami dirinya, jika individu telah mengetahui dan mau menerima kelebihan serta kekurangan yang ada pada dirinya. Hal ini diperkuat oleh pendapat Taylor, Peplau, Sears (2009: 119) yang menyatakan bahwa diri adalah keyakinan yang dipegang tentang diri sendiri, baik itu karakteristik, kelebihan, kelemahan, situasi apa yang disukai, dan dihindari.

Setelah individu memahami diri, diharapkan individu dapat mengoptimalkan potensi dan kelebihan yang dimiliki untuk mencapai kesuksesan di masa mendatang baik kesuksesan dalam hal belajar, berkarier, bergaul, berkeluarga, bermasyarakat, sukses dunia, dan sukses di akhirat. Disamping itu individu dapat menerima kekurangan yang dimiliki untuk diminimalisir atau dihilangkan sehingga tidak menimbulkan suatu masalah dalam kehidupan individu di masa mendatang. Akhirnya, pemahaman diri dapat membantu individu dalam menentukan arah dan tujuan hidup yang realistis, memiliki cita-cita yang sesuai dengan potensi diri, dan mencapai kematangan dalam karier. 
Pemahaman diri merupakan aspek penting bagi siswa SMA. Siswa yang memiliki pemahaman diri yang baik memiliki peluang yang lebih besar dalam mencapai kesuksesan daripada siswa yang memiliki pemahaman diri yang kurang. Hal ini diperkuat oleh pendapat Taylor et al (2009:121) menyatakan bahwa pemahaman diri yang lebih kokoh merupakan dasar untuk merencanakan kerja atau karier dan untuk menjalin hubungan yang lebih intim.

Berdasarkan hasil observasi peneliti saat melaksanakan PPL beberapa waktu yang lalu, masalah kurangnya pemahaman diri dialami oleh siswa kelas $\mathrm{X}$ di SMK SORE Kota Madiun khususnya kelas X Ak 3. Dari hasil observasi diketahui bahwa kurang lebih 70\% siswa kelas X Ak 3 memiliki pemahaman diri yang masih rendah. Hal ini ditandai dengan munculnya perilaku yang menyimpang (kurang adanya disiplin diri, kurangnya kesadaran akan tanggungjawab, kurang percaya diri, kurang memperhatikan pelajaran, sering berbicara sendiri atau bermain HP saat pelajaran berlangsung), perselisihan dengan teman sebaya, kurang memiliki pandangan diri yang jelas dan tujuan hidup. Mengingat akan pentingnya pemahaman diri dalam kaitannya pencapaian kesuksesan dalam hidup dan penyelesaian tugas perkembangan sosial remaja, maka masalah ini harus segera diselesaikan sehingga remaja dapat mempersiapkan diri memasuki masa dewasa.

Salah satu cara untuk meningkatkan pemahaman diri pada individu adalah dengan menggunakan model permainan Johari Window. Model permainan Johari Window digunakan untuk menggambarkan kesadaran diri (self-awareness) yang merupakan salah satu dimensi dari pemahaman diri. Ketika kesadaran diri individu meningkat, maka pemahaman diri individu juga akan meningkat. Hal ini diperkuat oleh pendapat Santrock (2003:335) yang menyatakan bahwa pemahaman diri remaja melibatkan adanya pengenalan komponen yang tidak disadari (unconscious) termasuk dalam dirinya, sama seperti halnya dengan komponen yang disadari (conscious). Dalam penelitian sebelumnya yang dilakukan oleh Newstrom \& Rubenfeld (1983:117), model permainan Johari Window dapat digunakan untuk membantu meningkatkan kesadaran dan pemahaman individu. 
Model permainan Johari Window dapat memfasilitasi individu dalam mengetahui kekurangan dan kelebihan yang ada pada dirinya berdasarkan sudut pandang dari diri sendiri dan orang lain dalam kelompoknya. Setelah individu mengetahui kekurangan dan kelebihan yang ada pada dirinya, maka pemahaman diri individu akan meningkat. Melalui permainan Johari Window, individu akan memperoleh umpan balik dari orang lain dalam kelompoknya, sehingga dapat meningkatkan pemahaman dirinya. Hal ini diperkuat oleh pendapat Johnson (dalam Supratiknya, 1995:21) yang menyatakan bahwa umpan balik dari orang lain yang dipercaya memang dapat meningkatkan pemahaman diri individu, yakni membuat individu sadar pada aspek-aspek diri serta konsekuensi-konsekuensi perilaku individu yang tidak pernah disadari sebelumnya. Disamping itu dengan menggunakan model permainan Johari Window, orang lain dalam kelompoknya dapat secara bebas mengungkapkan kekurangan dan kelebihan dari individu tanpa adanya rasa takut identitasnya akan diketahui. Model Permainan Johari Window ini juga lebih menarik dan tidak membosankan karena dilakukan dalam bentuk permainan.

Berdasarkan uraian masalah di atas, maka peneliti tertarik meneliti dengan judul: "Peningkatan Pemahaman Diri Melalui Model Permainan Johari Window Siswa Kelas X Ak 3 SMK SORE Kota Madiun Tahun Pelajaran 2012/2013”.

\section{KAJIAN TEORI}

\section{Model Permainan Johari Window}

Pada tahun 1955, Joseph Luft dan Harry Ingham (dalam Eka Wartana, 2012:90) memperkenalkan konsep Johari Window yang merupakan diagram untuk menggambarkan dan memperbaiki self awareness dan mutual understanding antar individu. Nama Johari diambil dari gabungan kedua nama orang tersebut yaitu Jo dan Harry, yang akhirnya disingkat menjadi Johari. Menurut Eka Wartana (2012:90), model Johari Window adalah alat yang sederhana dan sangat bermanfaat untuk menggambarkan kesadaran diri (self awareness), serta peningkatannya. Johari Window ini juga bisa dipakai untuk membina saling pengertian antar individu di dalam satu grup maupun antar grup. 
Dalam penelitian sebelumnya yang dilakukan oleh Newstrom \& Rubenfeld (1983:117), model permainan Johari Window dapat digunakan untuk membantu meningkatkan kesadaran dan pemahaman individu. Menurut Newstrom \& Rubenfeld (1983:117), model permainan Johari Window dapat digunakan untuk menggambarkan interaksi antara apa yang diketahui atau tidak diketahui untuk diri sendiri dan orang lain. Menurut Newstrom \& Rubenfeld (1983:118), model permainan Johari Window dapat diaplikasikan atau diterapkan di pelatihan, konseling atau di ruang kelas.

Joseph Luft dan Harrington Ingham (dalam Eka Wartana, 2012:90) mengembangkan konsep Johari Window sebagai perwujudan bagaimana seseorang berhubungan dengan orang lain yang digambarkan sebagai sebuah jendela. 'Jendela' tersebut terdiri dari 4 area diantaranya area terbuka, area buta, area tersembunyi, dan area gelap/tidak diketahui.

1. Area terbuka (Open Area) adalah apa yang diketahui oleh seseorang tentang dirinya dan juga diketahui oleh orang lain. Antara dirinya dan orang lain, terdapat kesesuaian pandangan. Pendapatnya tentang dirinya sama dengan pendapat orang-orang lain.

2. Area Buta (Blind Area) adalah apa yang tidak diketahui oleh seseorang tentang dirinya, tapi diketahui oleh orang lain.

3. Area Tersembunyi (Hidden Area) adalah apa yang hanya diketahui oleh dirinya, dan tidak diketahui oleh orang lain. Hal ini merupakan rahasia dirinya.

4. Area Gelap, Tidak Diketahui (Unknown Area) adalah apa yang tidak diketahui oleh seseorang tentang dirinya yang juga tidak diketahui oleh orang lain. Bila ada pemicu, apa yang tidak diketahui akan beralih ke area terbuka. 


\begin{tabular}{|l|l|l|}
\cline { 2 - 3 } Known to Others & Open Self & Blind Self \\
\cline { 2 - 3 } $\begin{array}{c}\text { Unknown to } \\
\text { Others }\end{array}$ & Hidden Self & Unknown area \\
\cline { 2 - 3 } & & \\
\hline
\end{tabular}

Gambar 1.1. Model Johari Window (Inge Hutagalung, 2007:16)

Dari uraian di atas, penulis menyimpulkan bahwa model Johari Window merupakan salah satu model permainan yang dapat digunakan untuk mengetahui kekurangan dan kelebihan yang dimiliki oleh individu dari sudut pandang diri individu itu sendiri dan orang lain dalam kelompoknya, sehingga dapat membantu meningkatkan kesadaran dan pemahaman diri individu. Menurut Suwardjo dan Eva (2011:97), pelaksanaan permainan Johari Window adalah sebagai berikut :

1. Kelas dibagi kelompok (misal masing-masing kelompok 12 orang).

2. Masing-masing anggota kelompok mengisi daftar isian yang telah disiapkan oleh konselor.

3. Setiap kelompok membentuk lingkaran kecil, kemudian daftar isian yang telah diisi diputar ke kanan. Hitungan satu berarti daftar isian berpindah ke teman sebelah kanan, kemudian masing-masing peserta mengisi daftar isian sesuai dengan apa yang dia ketahui tentang pemilik daftar isian tersebut. Setelah semua mengisi, daftar isian digeser ke kanan satu langkah untuk kembali orang lain mengisi begitu seterusnya sampai daftar isian kembali ke pemilik masing-masing.

4. Langkah selanjutnya adalah masing-masing peserta memetakan feedback (umpan balik dari teman) ke dalam Johari Window. Johnson (dalam Supratiknya, 1995:21) menyatakan bahwa umpan balik dari orang lain yang 
dipercaya dapat meningkatkan pemahaman diri individu, yakni membuat individu sadar pada aspek-aspek diri serta konsekuensi-konsekuensi perilaku individu yang tidak pernah disadari sebelumnya.

\section{Pemahaman Diri}

Santrock (2007:177) menyatakan bahwa pemahaman diri (selfunderstanding) adalah representasi kognitif remaja mengenai diri, substansi, dan isi dari konsepsi-diri remaja. Menurut Desmita (2010:180) pemahaman diri (sense of self) adalah suatu struktur yang membantu individu mengorganisasikan dan memahami tentang siapa dirinya, yang didasarkan atas pandangan orang lain, pengalaman-pengalamannya sendiri, dan atas dasar penggolongan budaya, seperti gender, ras, dan sebagainya. Menurut Seifert dan Hoffnung (dalam Desmita, 2010:180), pemahaman diri (sense of self) sering juga disebut konsep diri (selfconcept), yaitu suatu pemahaman mengenai diri atau ide tentang diri sendiri.

Harter (dalam Santrock, 2003:333) menyatakan bahwa pemahaman diri seorang remaja didasari oleh berbagai kategori peran dan keanggotaan yang menjelaskan siapakah diri remaja tersebut. Menurut Pikunas (dalam Hendrianti Agustiani, 2009:06), seorang remaja bukan sekedar mempertanyakan siapa dirinya, tapi bagaimana dan dalam konteks apa atau dalam kelompok apa dia bisa menjadi bermakna dan dimaknakan. Lebih lanjut Santrock (2003:335) menyatakan bahwa pemahaman diri remaja melibatkan adanya pengenalan komponen yang tidak disadari (unconscious) termasuk dalam dirinya, sama seperti halnya dengan komponen yang disadari (conscious).

Remaja membutuhkan kawan-kawannya untuk memperoleh dukungan dan penjelasan mengenai dirinya, termasuk mendengarkan pendapat kawan-kawannya dalam proses mendefinisikan siapakah dirinya itu. Hal ini diperkuat oleh pendapat Friedman \& Schustack (2008:342) yang menyatakan bahwa orang mendapatkan pemahaman diri melalui lingkungan psikososial yang suportif.

Dari uraian di atas, penulis menyimpulkan bahwa pemahaman diri merupakan gambaran kognitif individu mengenai dirinya (potensi, kelebihan 
maupun kekurangan), isi dari konsepsi diri individu, dan pemahaman mengenai dirinya baik yang disadari (conscious) maupun yang tidak disadari (unconscious).

Pemahaman diri merupakan aspek yang penting bagi individu. Adapun tujuan dari pemahaman diri adalah sebagai berikut :

1. Pemahaman diri memberikan dasar identitas diri yang rasional.

2. Pemahaman diri membantu individu merencanakan karier dan menjalin hubungan yang lebih intim dengan orang lain.

3. Pemahaman diri membantu individu memberikan arah dan tujuan hidup.

4. Pemahaman diri membantu meningkatkan konsep diri individu dan membantu individu mencapai keberhasilan.

Adapun Ciri-Ciri Individu yang Memiliki Pemahaman Diri

1. Memiliki kesadaran diri, baik kekurangan, kelebihan ataupun potensi yang dimiliki.

2. Memiliki keinginan kuat untuk melakukan perubahan kearah kondisi yang lebih baik dan lebih percaya diri.

3. Individu yang memahami dirinya adalah individu yang dapat berfikir positif tentang kekurangan, kelebihan dan potensi yang dimiliki.

4. Memiliki kepercayaan bahwa hidupnya bermakna.

5. Memiliki dan berusaha untuk mencapai arah dan tujuan hidup.

\section{METODE PENELITIAN}

Penelitian ini dilakukan di SMK SORE Kota Madiun, yang beralamat dijalan Kelapa Manis 41 Madiun. Tempat penelitian ini dipilih setelah dilakukan observasi terhadap sekolah-sekolah menengah atas di sekitar wilayah Kota Madiun. Hasil observasi menunjukkan bahwa di sekolah tempat penelitian banyak ditemukan karakteristik masalah yang sedang diteliti, sehingga sekolah ini kemudian dipilih sebagai tempat penelitian. Penelitian dilaksanakan pada bulan Februari sampai dengan bulan Juli 2013, dengan subjek penelitian siswa kelas X Ak 3 SMK SORE Kota Madiun tahun pelajaran 2012/2013 sejumlah 20 siswa.

Metode penelitian dalam penelitian ini menggunakan metode eksperimen. Menurut Sugiyono (2010:107), metode penelitian eksperimen adalah metode 
penelitian yang digunakan untuk mencari pengaruh perlakuan tertentu terhadap yang lain dalam kondisi yang terkendalikan. Eksperimen selalu dilakukan dengan maksud untuk melihat akibat suatu perlakuan.

Rancangan penelitian eksperimen yang dipilih adalah rancangan pre eksperimental design dengan desain pre-test and post test group. Suharsimi Arikunto (2010:124) menjelaskan bahwa di dalam design pre-test and post test group ini observasi dilakukan sebanyak 2 kali yaitu sebelum eksperimen dan sesudah eksperimen. Dengan demikian peneliti dapat membandingkan keadaan sebelum eksperimen dengan keadaan sesudah eksperimen.

Penerapan metode eksperimen pada penelitian ini, siswa diberi model permainan Johari Window dan diharapkan siswa dapat mengetahui kekurangan dan kelebihan yang dimiliki, sehingga siswa dapat meningkatkan pemahaman dirinya setelah melakukan permainan. Subyek dalam penelitian ini adalah siswa kelas X Ak 3 SMK SORE Kota Madiun yang berjumlah 20 siswa yang diperoleh dari data siswa catatan konselor sekolah. Penetapan sampel pada penelitian ini menggunakan teknik sampling jenuh dimana semua anggota populasi digunakan sebagai sampel penelitian.

Instrumen penelitian dan teknik pengumpulan data untuk mengungkap data tentang peningkatan pemahaman diri siswa melalui model permainan Johari Window dalam penelitian ini menggunakan angket dan form Johari Window. Angket digunakan untuk mengetahui tingkat pemahaman diri siswa sebelum dan sesudah diberikan model permainan Johari Window. Form Johari Window digunakan untuk mengetahui feedback (umpan balik) dari teman-teman yang dapat meningkatkan pemahaman diri siswa.

Adapun analisis data dalam penelitian ini menggunakan teknik t-test dengan rumus :

$$
\boldsymbol{t}=\frac{\boldsymbol{M d}}{\sqrt{\frac{\sum X^{2} d}{N(N-1)}}} \quad \text { (Suharsimi Arikunto, 2010: 349) }
$$




\section{HASIL PENELITIAN}

1. Deskripsi data sebelum diberikan model permainan Johari Window adalah jumlah nilai $=1230$, Mean nilai atau rata-rata $=61,75$, Median atau nilai tengah 62,86, Modus atau nilai yang sering muncul 65,08. Nilai terendah adalah 52 sedangkan nilai tertinggi 71 .

2. Deskripsi data sesudah diberikan model permainan Johari Window adalah jumlah nilai $=1290$, Mean nilai atau rata-rata $=64,05$, Median atau nilai tengah 65,5, Modus atau nilai yang sering muncul 68,4. Nilai terendah adalah 54 sedangkan nilai tertinggi 75.

3. Hasil pengujian hipotesis tentang peningkatan pemahaman diri siswa sebelum dan sesudah diberikan model permainan Johari Window menunjukkan $t_{\text {hitung }}=3,295$. Untuk mengetahui apakah $t_{\text {hitung }}=3,295$ signifikan atau tidak signifikan, maka perlu dikonsultasikan dengan $t_{\text {tabel }}$. Harga $t_{\text {tabel }}$ dengan d.b 19 adalah 2,093/t=95\%. Jadi $t_{\text {hitung }}=3,295>t_{\text {tabel }}=2,093$ yang berarti signifikan atau ada peningkatan.

4. Setelah diberikan model permainan Johari Window, tingkat pemahaman diri siswa naik sebesar $4 \%$.

\section{SIMPULAN}

Berdasarkan hasil penelitian dan pembahasan pada bab sebelumnya maka diambil kesimpulan bahwa ada peningkatan pemahaman diri melalui model permainan Johari Window siswa kelas X Ak 3 SMK SORE Kota Madiun tahun pelajaran 2012/2013.

\section{DAFTAR PUSTAKA}

Desmita. 2010. Psikologi Perkembangan. Bandung : Rosda Karya

Eka Wartana. 2009. Mind Web Konsep Berfikir Tanpa Mikir. Jakarta : Gramedia Pustaka Utama

Friedman \& Schustack. 2008. Kepribadian Teori Klasik dan Riset Modern. Jakarta : Erlangga

Hendrianti Agustiani. 2009. Psikologi Perkembangan (Pendekatan Ekologi Kaitannya dengan Konsep Diri dan Penyesuaian Diri pada Remaja. Bandung : Refika Aditama 
Newstrom \& Rubenfeld. 1983. The Johari Window : Reconceptualization.

Developments in Business Simulation \& Experiential Exercises, Volume 10 :

117-120 (http://sbaweb.wayne.edu/ absel/bkl/vol10/10be.pdf, diakses 18 Februari 2013)

Santrock. 2003. Adolescence Perkembangan Remaja. Jakarta : Erlangga . 2007. Remaja. Jakarta : Erlangga

Sugiyono. 2010. Metode Penelitian Kuantitatif, Kualitatif dan R\&D. Bandung : Alfabeta

Supratiknya. 1995. Komunikasi Antar Pribadi Tinjauan Psikologis. Yogyakarta : Kanisius

Suharsimi Arikunto. 2010. Prosedur Penelitian Suatu Pendekatan Praktik. Jakarta : Rineka Cipta

Suwardjo dan Eva. 2010. 55 Permainan Dalam Bimbingan dan Konseling. Yogyakarta : Paramitra

Taylor, Peplau, dan Sears. 2009. Psikologi Sosial, Edisi Kedua Belas. Jakarta : Kencana 